\title{
Investigation of Some Variables of Posttraumatic Stress Disorder (PTSD), Empathy and Depression in Syrian Children
}

\author{
Gökhan Şengün, Ayșe Dilek Öğretir* \\ Department of Child Development, Institute of Education Science, Gazi University, Ankara, Turkey
}

Copyright(C2018 by authors, all rights reserved. Authors agree that this article remains permanently open access under the terms of the Creative Commons Attribution License 4.0 International License

\begin{abstract}
Turkey has been facing with migration for various reasons. More than half of those migrating from Syria to Turkey are children. In this study, it was aimed to examine the levels of PTSD, empathy and depression in Syrian children. A total of 121 boys and 135 girls from Altındağ district of Ankara formed a sample group of 256 children. Personal Information Form, PTSD, Empathy and Depression Scale for Children were used in this study. The results revealed that there was no meaningful relation between the gender of the children and the levels of PTSD, empathy and depression. The younger children's trauma level and depression level was higher as well as the children whose father is alive. The empathy level is also higher and children's PTSD and empathy levels have changed according to their siblings are alive or not. The depression level of children whose mothers did not work was higher. Children whose fathers did not work had a higher level of PTSD, empathy and depression. Children with violence in the family had high levels of PTSD, empathy and depression, the empathy level of children with fewer siblings was lower, children whose income level was lower depression level was lower.
\end{abstract}

Keywords PTSD, Empathy, Depression, Migration, Syrian Children and Adolescents

\section{Introduction}

Recently, there have been traumatic events in almost every part of the World and thus people are trying to overcome them. Although all traumatic events share some common features, they differ in their impact on individuals. Traumatic events affect societies from many aspects such as geopolitical, economic, social, political, psychological, etc. [1]. Many people develop acute stress responses such as arousal, anxiety, sadness, grief, irritability, and sleep disturbances immediately after they have been exposed to a life-threatening traumatic event. Although these symptoms disappear over time, some individuals may develop a more permanent series of psychological symptoms [2]. The most common psychological disorder after trauma is post-traumatic stress disorder (PTSD) [3]. PTSD was accepted as a psychiatric disorder by APA in 1980 [4]. Criteria for PTSD were revised in later versions [5] and PTSD was classified as an international disease by the World Health Organization (WHO) [6]. Garrison, Weinrich, Hardin, Weinrich and Wang [7] suggest that some traumatic events reveal more PTSD symptoms than others.

The situation of Syrian refugees has recently been one of the negative events that have affected humanity in a destructive manner. From 2011, when the war began in Syria, until today, half of the Syrian population migrated to Turkey and several other countries in order to get rid of the traumatic situation they experienced. Due to the several reasons such as geopolitical location and war, millions of people migrated to Turkey several times throughout history [8]. Turkey has not left Syrian people alone in such a difficult situation and has been maintaining the support they need [9]. Currently, Turkey is home to more than 3 million Syrian refugees more than half of whom are children in the age of education [10]. According to the latest data from the Ministry of National Education (MoNE), approximately 325,000 Syrian children are registered in schools or temporary educational centres throughout the country. Syrian children in Turkey need educational and psychological support [11]. Syrian children experience negative attitudes of their classmates in their schools. At this point Coşkun[12] reports that Syrian students have serious adaptation problems as a result of their heavy trauma and their habituation to a different country as a whole. However, the real adaptation problem for these students has emerged in public schools. Research shows that traumatic experiences affect 
adolescents differently from children and adults. Coffman[13] argues that children's reactions to traumatic events should be examined by taking developmental levels into account.

Empathy is an important part of normal social functioning. Empathy is defined as the person's spontaneous and naturally fulfilling his/her feelings and thoughts by putting himself / herself in the position of the other person [14]. Empathy is defined in different ways by philosophy, psychology and neurology. Justin D'arms describes empathy as "feeling someone else's feelings" by reacting to someone's feelings as both action and capacity. Philosopher Peter Goldie and Robert Gordon emphasize the creative or simulated aspect of empathy. Goldie describes empathy as "a person's center of thought and emotion" [15]. Matthews, Zeidner and Roberts[16] defined empathy as the tendency of individuals to focus on one another in interpersonal relationships, recognizing what they think or how they feel, and reacting to the other's emotions.

Depression is a common and serious medical condition that affects the behaviors the people feel, the way the people think and behave. Depression can lead to emotional and physical problems and may prevent a person from working at work and at home [17]. The factors that trigger depression in childhood are said to include low socio-economic levels, living conditions, traumatic events, etc. It is observed that nowadays depression exists in children and has similar characteristics to that of adults [18]. In this context, it is of great importance to provide psycho-social support for the individual and social development of Syrian children. It is known that traumatic situations are frequently seen in Syrian families and especially children migrating to Turkey after the war in Syria. In this study, we aimed to investigate the post-traumatic stress disorder, empathy and depression levels in Syrian children in terms of some variables.

\section{Materials and Methods}

\subsection{Sample}

A total of 256 children, 121 boys and 135 girls migrating to Turkey after the war in Syria, who were educated at temporary education centers in Altındağ, Ankara Province, were participated in the study. Syrian children who constitute the study group were randomly selected from temporary education centers in Altındağ district of Ankara province during the fall semester of the 2017-208 academic year. These students experienced trauma due to the war in Syria and some of them lost their first-degree relatives in the war in Syria. Büyüköztürk [19] argues that the researchers should be careful about the size of the working group in order to show the relationships in a reliable way, and the working group should be of the appropriate size. In this research, it was applied in Altındağ district of Ankara because of the region where Syrian refugees live intensively. The analysis was carried out by SPSS 20 program.

\subsection{Data Collection Tools}

\subsubsection{Personal Information Form}

A "Personal Information Form" has been prepared in order to gather information about Syrian children and their families in the study. The form was developed by the researcher, taking the expert opinion. The form includes questions to determine demographic information for the child and his / her family.

\subsubsection{Post Traumatic Stress Disorder Scale for Children}

The Post Traumatic Stress Disorder Scale for Children is a scale designed to assess the severity of post-traumatic stress disorder in children and adolescents aged 8-18 years, consisting of a total of 24 items and two parts. The scale was developed by Frederick [20] and standardization was performed on 750 children and 1350 adults. Internal consistency coefficients (Cronbach's alpha) of the scale subscales were calculated as $0.80,0.69$ and 0.68 , respectively [21]. In the "test-retest" reliability study of the PTSD scale for children, the scorers were found as $94 \%$ and the Cohen K coefficient as .88. Conversion of the scale to Turkish and pre-validity and reliability studies were carried out by Erden, Kilic, Uslu and Kerimoğlu [22] and the reliability of the scale was "test retest" .86 , internal consistency coefficient .75 and interintegration consistency coefficient $(\mathrm{K}=.87)$.

\subsubsection{Empathy Scale for Children}

Bryant [23] worked on the development and validation of an empathy index for children and adolescents, who are 56 first-year students, 115 fourth-grade students, and 87 seventh-grade students. After the research, Bryant [23] developed the Empathy Scale for Children and Adolescents. This scale was adapted from Mehrabian and Epstein's [24] empathy scale for adults. Studies of adaptation of the scale to Turkish have been carried out by Yilmaz [25]. The scale, originally consists of 22 items, has been reduced to 20 items as a result of Turkish adaptation studies. Children react to scales in the form of yes or no questions according to what they express for themselves. "1" stands out "yes" answer and "0" represents "no" answer, and high score means high empathy. Empathy Scale for Children held in Turkey on the validity, reliability coefficient was found to be $r=.69$. The internal consistency (cronbach alpha) coefficient for the Empathy Scale for Children was found to be .70 .

\subsubsection{Depression Scale for Children}

The Depression scale for children developed by Kovacs [26] is based on the Beck depression scale. However, 
questions about situation specific areas such as childhood depression, school, friends and relationships included to the scale. The scale, gained by Öy [27] in Turkish, has 27 items. According to the severity of the symptoms, ' 0 ', ' 1 ' or ' 2 ' points are given and the highest score is 54 . High scores indicate high depression level. Validity and reliability studies in Turkish context was carried out by Öy[27].

\subsubsection{Process}

The personal information form and scales used in the present study were first translated into Arabic from Turkish. Afterwards, an expert who speaks Arabic examined and made necessary corrections. In October, 2017, the researcher visited the classes with Arabic-speaking teachers and gave information about the research and provided the necessary explanations. Students were motivated to practice by explaining the purpose of research, how to evaluate the results and the benefits the study would provide. Furthermore, in order for the answers to reflect the truth, it is stated that students should not write their names on the forms given to them, and that the participation in the present study will be based on the volunteer basis and that they will not be used elsewhere.

\subsubsection{Data Analysis}

Two-way analysis of variance (ANOVA) was used to determine whether traumatic symptoms, empathy level and depression levels differed according to some personal characteristics of the students. The independent variables consist of gender (boys, girls), age, and so on. Dependent variables are the total scores of PTSD Scale, Empathy Scale and Depression Scale. It was investigated to what extent the ANOVA quantities of the data would be met in the first step of the analysis process. For this purpose, loss value analysis, homogeneity of variances, contradictory observation, normality and independence were examined. As a result of these examinations, the data were found to meet all the necessary qualifications for ANOVA.

\subsubsection{Results}

Table 1 shows that 135 (52.7\%) of the participants were girls and $121(47.3 \%)$ were boys. When their ages investigated it was revealed that $91(35.5 \%)$ were $8-9$ years old, $120(46.9 \%)$ were $10-11$ years old and $45(17.6 \%)$ were 12-15 years old. According to the number of brothers and sisters it was found that $35(13,7 \%)$ were single children, $38(14,8 \%)$ were two brothers, $63(24,6 \%)$ were three brothers and four (120) (46,9\%) were siblings. According to the siblings' survival status, 112 (43.8\%) of them reported that their siblings were alive whereas 144 $(56.2 \%)$ of them stated that they were not alive. 245 (95.7\%) of the Syrian children expressed that their mothers were alive, while $11(4.3 \%)$ of them said that their mothers were not alive. The number of Syrian children whose father was alive $218(85,2 \%)$ while the number of Syrian children whose father was not alive $38(14,8 \%)$. According to the answers given by the Syrian children, it was known that the mother and father of 199 were alive $(77,7 \%), 11$ mothers were dead $(4,2 \%), 38$ fathers were dead $(14,8 \%)$. It was found that the mothers of Syrian children, 48 (18.8\%) were not reading and writing, $141(55.1 \%)$ were literate or primary school graduates, $49(19.1 \%)$ were middle school graduates, $14(5.5 \%)$ were high school graduates and 4 $(1.6 \%)$ were university graduates. $(50.8 \%)$ were literate or primary school graduates, 64 (25\%) were middle school, $15(5.9 \%)$ were not reading and writing in the $40(15.6 \%)$. The fathers of the Syrian students, 15 of their fathers high school graduates and $7(2.7 \%)$ were university graduates. The finding indicates that the vast majority of Syrian families have a low education level.

Table 1. Frequency Distributions of Demographic Characteristics of Syrian Children

\begin{tabular}{|c|c|c|c|}
\hline Variables & Categories & $\mathbf{n}$ & $\%$ \\
\hline \multirow{2}{*}{ Gender } & Girls & 135 & 52,7 \\
\hline & Boys & 121 & 47,3 \\
\hline \multirow{3}{*}{ Age } & 8-9 year & 91 & 35,5 \\
\hline & $10-11$ year & 120 & 46,9 \\
\hline & 12-15year & 45 & 17,6 \\
\hline \multirow{4}{*}{$\begin{array}{c}\text { Number of } \\
\text { Brothers or } \\
\text { Sisters }\end{array}$} & Single Child & 35 & 13,7 \\
\hline & 2 Brothers or Sisters & 38 & 14,8 \\
\hline & 3 Brothers or Sisters & 63 & 24,6 \\
\hline & 4 and more Brothers or Sisters & 120 & 46,9 \\
\hline \multirow{2}{*}{$\begin{array}{c}\text { Are your } \\
\text { brothers alive? }\end{array}$} & Alive & 112 & 43,8 \\
\hline & Dead & 144 & 56,2 \\
\hline \multirow{2}{*}{$\begin{array}{c}\text { Is your mother } \\
\text { alive? }\end{array}$} & Alive & 245 & 95,7 \\
\hline & Dead & 11 & 4,3 \\
\hline \multirow{2}{*}{$\begin{array}{l}\text { Is your father } \\
\text { alive? }\end{array}$} & Alive & 218 & 85,2 \\
\hline & Dead & 38 & 14,8 \\
\hline \multirow{5}{*}{$\begin{array}{c}\text { Mother's } \\
\text { Education } \\
\text { Level }\end{array}$} & Not literate & 48 & 18,8 \\
\hline & $\begin{array}{l}\text { Literate or primary school } \\
\text { graduate }\end{array}$ & 141 & 55,1 \\
\hline & Secondary school graduate & 49 & 19,1 \\
\hline & High school graduate & 14 & 5,5 \\
\hline & College or faculty graduate & 4 & 1,6 \\
\hline \multirow{5}{*}{$\begin{array}{l}\text { Father's } \\
\text { Education } \\
\text { Level }\end{array}$} & Not literate & 40 & 15,6 \\
\hline & $\begin{array}{c}\text { Literate or primary school } \\
\text { graduate }\end{array}$ & 130 & 50,8 \\
\hline & Secondary school graduate & 64 & 25,0 \\
\hline & High school graduate & 15 & 5,9 \\
\hline & College or faculty graduate & 7 & 2,7 \\
\hline \multirow{3}{*}{$\begin{array}{c}\text { Average } \\
\text { income level } \\
\text { of the family }\end{array}$} & $0-600 \mathrm{tl}$ & 61 & 23,8 \\
\hline & 601-1500tl & 178 & 69,5 \\
\hline & $1501-3000 \mathrm{tl}$ & 17 & 6,6 \\
\hline \multirow{2}{*}{$\begin{array}{c}\text { Father's } \\
\text { working status }\end{array}$} & Not working & 66 & 25,8 \\
\hline & Working & 190 & 74,2 \\
\hline \multirow{2}{*}{$\begin{array}{c}\text { Mother's } \\
\text { working status }\end{array}$} & Not working or housewife & 196 & 76,6 \\
\hline & Working & 60 & 23,4 \\
\hline \multirow{2}{*}{$\begin{array}{l}\text { Violence in the } \\
\text { family }\end{array}$} & Violence & 177 & 69,1 \\
\hline & No Violence & 79 & 30,9 \\
\hline
\end{tabular}

According to the income level variable of the family of Syrian students, $61(23.8 \%)$ of them reported that the 
income their family received was between 0-600 TL, 178 $(69.5 \%)$ of them said that the income their family received was between 601-1500 TL, $17(6,6 \%)$ of them expressed that the income their family received was between 1501-3500 TL. The finding indicates that the vast majority of Syrian families have a socioeconomic level.

According to the father's working status variable, the number of the working parents of the Syrian students was $66(25,8 \%)$ while the number of working fathers was 190 $(74,2 \%)$. According to the working status of the mother, 196 (76.6\%) of the mothers were housewives or were not working and $60(23.4 \%)$ of working mothers were distributed. In view of the livelihood in the family; 177 children reported experiencing violence in the family $(69.1 \%)$ and 79 children $(30.9 \%)$ reported that there was no violence in the family.

Table 2. T-test Results of Total Scores of PTSD, Empathy and Depression Scales of Syrian Children by Gender

\begin{tabular}{|c|c|c|c|c|c|c|c|}
\hline Varible & Gender & $\mathrm{n}$ & $\overline{\mathrm{X}}$ & S & $\mathrm{sd}$ & $\mathrm{t}$ & $\mathrm{P}$ \\
\hline PTSD & $\begin{array}{l}\text { Girls } \\
\text { Boys }\end{array}$ & $\begin{array}{l}135 \\
121\end{array}$ & $\begin{array}{l}37,12 \\
37,20\end{array}$ & $\begin{array}{l}9,32 \\
9,68\end{array}$ & 254 &,- 068 & ,946 \\
\hline Empathy & $\begin{array}{l}\text { Girls } \\
\text { Boys } \\
\end{array}$ & $\begin{array}{l}135 \\
121 \\
\end{array}$ & $\begin{array}{c}9,68 \\
10,09 \\
\end{array}$ & $\begin{array}{l}2,14 \\
2,16 \\
\end{array}$ & 254 & $-1,491$ & ,137 \\
\hline Depression & $\begin{array}{l}\text { Girls } \\
\text { Boys }\end{array}$ & $\begin{array}{l}135 \\
121 \\
\end{array}$ & $\begin{array}{l}29,94 \\
30,35\end{array}$ & $\begin{array}{l}4,83 \\
5,29 \\
\end{array}$ & 254 &,- 643 &, 521 \\
\hline
\end{tabular}

$* \mathrm{p}<.05 . * * \mathrm{p}<.01$

In this study, according to Table 2, there was no significant difference between the gender according to the PTSD, Empathy and Depression Scales of the Syrian children. In contrast, Jolliffe and Farrington [28], 363 adolescents around 15 years of age were employed in the study called Development and Validity of the Basic Empathy Scale, and 357 different adolescents were reapplied after 1 year. In this study, girls were rated higher than boys in terms of both emotional and cognitive empathy. Aysev, Ulukol and Ceyhun [29] found that "working and reading children are evaluated with the" Depression Scale for Children "in the study results that gender was not effective on depressive symptoms in 6-12 year old children. As seen in this research, the effects of wars are more evident in children. Based on the findings it can be said that the war affects boys and girls in the same way negatively.

Table 3 showed that whether or not the siblings of the Syrian children were alive significantly related to the Empathy Scale total score $(p=0.002<0.05)$. The empathy point average $(\bar{X}=9,40)$ for sibling children was lower than the empathy point average $(\bar{X}=10,25)$ for sibling children. Children with siblings that are alive had a higher mean PTSD score $(\overline{\mathrm{X}}=38,41)$ than children with siblings that were dead $(\overline{\mathrm{X}}=36,18)$.

Table 3. T-test Results of Total Scores of PTSD, Empathy and Depression Scales According to whether their siblings were alive or not

\begin{tabular}{|c|c|c|c|c|c|c|c|}
\hline Variable & $\mathrm{A}$ & $\mathrm{n}$ & $\overline{\mathrm{X}}$ & $\mathrm{S}$ & $\mathrm{sd}$ & $\mathrm{t}$ & $\mathrm{p}$ \\
\hline \multirow{2}{*}{ PTSD } & Alive & 112 & 38,41 & 8,57 & \multirow{2}{*}{254} & \multirow{2}{*}{1,879} & \multirow{2}{*}{, 061} \\
& Dead & 144 & 36,18 & 10,04 & & & \\
\hline \multirow{2}{*}{ Empathy } & Alive & 112 & 9,40 & 2,00 & \multirow{2}{*}{254} & $-3,172$ &, $002 * *$ \\
& Dead & 144 & 10,25 & 2,20 & & & \multirow{2}{*}{, 323} \\
\hline \multirow{2}{*}{ Depression } & Alive & 112 & 29,78 & 5,20 & \multirow{2}{*}{254} &,- 990 & \\
& Dead & 144 & 30,41 & 4,94 & & &
\end{tabular}

$* * \mathrm{p}<.01 \mathrm{~A}$ : Whether your brother or sister were alive or not

Although some studies have shown that the symptoms of PTSD in children have disappeared over time, some studies have found that PTSD symptoms persist for years [30]. Some researchers also state that some children and adolescents were resistant to the stress despite their trauma life because of their personality structure, and that not everyone who develops trauma develops PTSD [31]. The empathy level of the Syrian children, whose siblings were dead, was higher than the children whose siblings were alive. The reason of this may be the experience they had because they lost their siblings at the war.

Table 4. T-test Results of Total Scores of PTSD, Empathy and Depression Scales whether their fathers were alive or not

\begin{tabular}{|c|c|c|c|c|c|c|c|}
\hline Varible & A & $\mathrm{n}$ & $\overline{\mathrm{X}}$ & $\mathrm{S}$ & sd & $\mathrm{t}$ & $\mathrm{P}$ \\
\hline PTSD & $\begin{array}{l}\text { Alive } \\
\text { Dead }\end{array}$ & $\begin{array}{c}218 \\
38\end{array}$ & $\begin{array}{l}37,42 \\
35,65\end{array}$ & $\begin{array}{c}9,28 \\
10,51\end{array}$ & 254 & 1,062 & 289 \\
\hline Empathy & $\begin{array}{l}\text { Alive } \\
\text { Dead }\end{array}$ & $\begin{array}{c}218 \\
38\end{array}$ & $\begin{array}{l}9,93 \\
9,57\end{array}$ & $\begin{array}{l}2,11 \\
2,40\end{array}$ & 254 &,- 928 & ,354 \\
\hline Depression & $\begin{array}{l}\text { Alive } \\
\text { Dead }\end{array}$ & $\begin{array}{c}218 \\
38\end{array}$ & $\begin{array}{l}30,50 \\
28,07\end{array}$ & $\begin{array}{l}5,11 \\
4,16\end{array}$ & 254 & 2,759 &, $006 * *$ \\
\hline
\end{tabular}

** $\mathrm{p}<.01 \mathrm{~A}$ : Whether their father were alive or not

According to Table 4, the average of empathy scores of children whose father was alive $(\bar{X}=9,93)$ was slightly higher than the empathy scores of children whose father was not alive $(\bar{X}=9,57)$. This finding can be interpreted as the higher level of empathy among Syrian children than those whose fathers were alive and whose fathers were not alive. According to the total scores of the depression scale of Syrian children, there was a significant difference between the children whether their fathers were alive $(\overline{\mathrm{X}}$ $=30,50$ ) or dead $\bar{X}=28,07$ ). This finding can be interpreted as if their fathers were alive they feel more depression because of getting fear of losing their fathers. The reason of this may be because they witnessed the other children' father were dead in the war. Some researchers investigating adolescents' personality traits, the type and severity of trauma, short or long-term continuation of symptoms of PTSD reported that it was effective [32] . 
Table 5. T-test Results of Syrian Children Total Scores of PTSD, Empathy and Depression Scales whether their fathers were working or not

\begin{tabular}{|c|c|c|c|c|c|c|c|}
\hline Variable & A & $\mathrm{n}$ & $\overline{\mathrm{X}}$ & S & sd & $\mathrm{t}$ & $\mathrm{p}$ \\
\hline PTSD & $\begin{array}{c}\text { NW } \\
\text { W }\end{array}$ & $\begin{array}{c}66 \\
190\end{array}$ & $38,8036,59$ & $\begin{array}{l}9,70 \\
9,35\end{array}$ & 254 & 1,636 & ,289 \\
\hline Empathy & $\begin{array}{c}\text { NW } \\
W\end{array}$ & $\begin{array}{c}66 \\
190\end{array}$ & $\begin{array}{c}10,06 \\
9,81\end{array}$ & $\begin{array}{l}2,04 \\
2,19\end{array}$ & 254 &, 793 &, 354 \\
\hline Depression & $\begin{array}{c}\text { NW } \\
\text { W }\end{array}$ & $\begin{array}{c}66 \\
190\end{array}$ & $\begin{array}{l}31,72 \\
29,58\end{array}$ & $\begin{array}{l}4,69 \\
5,07\end{array}$ & 254 & 3,005 &, $006 * *$ \\
\hline
\end{tabular}

** $\mathrm{p}<.01 \mathrm{~A}$ : Whether their fathers were working or not

W: Working

NW: Not working

According to Table 5, the average of PTSD score for children whose fathers were not working $(\bar{X}=38,80)$ was higher than the average of PTSD score $(\overline{\mathrm{X}}=36,59)$ for children whose fathers were working. According to the depression scale total scores of Syrian children, there was a significant difference between the children whose fathers were working or not. Similarly, the mean score of empathy for children whose fathers were not working $(\bar{X}=10.06)$ was higher than the average score for empathy of children whose fathers were working $(\bar{X}=9.81)$. The children's, whose fathers were not working, mean scores of depression $(\bar{X}=31.72)$ was higher children's, whose fathers were working, mean scores of depression $(\bar{X}=29.58)$. These findings can be explained by the fact that the levels of PTSD, empathy and depression of the children whose fathers were not working were higher than the children whose fathers were working. Therefore, the children whose fathers were working may feel more confidence and less depression. This finding suggests that $25 \%$ of fathers of Syrian children do not work. This result was consistent with the findings of a study that parents with low socioeconomic status have higher levels of depression in their children [33].

Table 6. T-test results of Syrian children PTSD, empathy and depression scales total scores according to whether their mothers were working or not

\begin{tabular}{|c|c|c|c|c|c|c|c|}
\hline Variable & $\mathrm{A}$ & $\mathrm{n}$ & $\overline{\mathrm{X}}$ & $\mathrm{S}$ & $\mathrm{sd}$ & $\mathrm{t}$ & $\mathrm{p}$ \\
\hline \multirow{2}{*}{ PTSD } & $\mathrm{NW}$ & 196 & 37,18 & 9,57 & 254 &, 06 &, 952 \\
& $\mathrm{~W}$ & 60 & 37,10 & 9,21 & &, & \\
\hline \multirow{2}{*}{ Empathy } & $\mathrm{NW}$ & 196 & 9,85 & 2,16 & 254 &,- 35 &, 720 \\
& $\mathrm{~W}$ & 60 & 9,96 & 2,14 & & & \\
\hline \multirow{2}{*}{ Depression } & $\mathrm{NW}$ & 196 & 30,62 & 4,93 & 254 & 2,79 &, $006^{* *}$ \\
\hline
\end{tabular}

** $\mathrm{p}<.01 \mathrm{~A}$ : Whether their mothers were working or not W: Working

NW: Not working

According to Table 6, there was a significant difference according to the total scores of Syrian Depression Scale according to whether or not their mothers were working. The mean score of the children, whose mothers were not working, $(\bar{X}=37,18)$ was higher than those of the children whose mothers were working $(\bar{X}=37,10)$. The children's mean score of empathy, whose mothers were working $(\overline{\mathrm{X}}=$ $9,96)$ was higher than the children whose mothers were not working $(\bar{X}=9.85)$. Jolliffe and Farrington [14] found that empathy was positively associated with the socio-economic situation in his research on the development and validity of the Essential Empathy Scale. The mean depression scores of the children, whose mothers were not working $(\bar{X}=30.62)$ was higher than those of the children, whose mothers were working $(\bar{X}=28.56)$. This finding can be explained as the depression level of the children whose mothers were not working was higher than the children whose mothers were working. It can be said that the children whose mothers were working may feel more confidence and less depression.

Table 7. T-test results of Syrian children according to the total scores of PTSD, empathy and depression scales for violence in the family

\begin{tabular}{|c|c|c|c|c|c|c|c|}
\hline Variable & $\mathrm{A}$ & $\mathrm{n}$ & $\overline{\mathrm{X}}$ & $\mathrm{S}$ & $\mathrm{sd}$ & $\mathrm{t}$ & $\mathrm{p}$ \\
\hline \multirow{2}{*}{ PTSD } & $\mathrm{V}$ & 177 & 38,14 & $9,409,33$ & 254 & 2,495 & \multirow{2}{*}{, $013^{*}$} \\
& $\mathrm{NV}$ & 79 & 34,97 & & & & \\
\hline \multirow{2}{*}{ Empathy } & $\mathrm{V}$ & 177 & 9,97 & $2,241,96$ & 254 & 1,093 & \multirow{2}{*}{, 276} \\
& $\mathrm{NV}$ & 79 & 9,65 & & & & \\
\hline \multirow{2}{*}{ Depression } & $\mathrm{V}$ & 177 & 30,71 & 5,25 & 254 & 2,740 &, $007 * *$ \\
& $\mathrm{NV}$ & 79 & 28,86 & 4,34 & & & \\
\hline
\end{tabular}

$* \mathrm{p}<.05 . * * \mathrm{p}<.01$

A: Is there violence in the family?

V: Violence NV: No Violence

According to Table 7, there was a significant difference according to the total scores of PTSD and depression scale of Syrian children according to whether or not there was violence in the family. The mean PTSD score of children with violence in the family $(\bar{X}=38,14)$ was higher than the PTSD score $(\bar{X}=34.97)$ of children without violence in the family. The mean total empathy score of children with family violence in the family $(\overline{\mathrm{X}}=9.97)$ was slightly higher than the mean of the empathy score $(\bar{X}=9.65)$ of the children without violence in the family. The mean depression score $(\overline{\mathrm{X}}=30.71)$ for children with family violence in the family was higher than the mean depression score $(\bar{X}=28.86)$ for children without family violence in the family. These findings indicated that the levels of PTSD, empathy and depression of Syrian children with family violence in the family were higher than the PTSD, empathy and depression levels in Syrian children without family violence. According to this finding, it can be said that violence in the family may trigger PTSD and depression of Syrian children. Okcu[34] investigated the factors related to the development and severity of PTSD in children who were exposed to trauma, and as the depression increased, PTSD also increased. In study conducted by Okcu[34]; a 
large majority of children experiencing problems with their parents were found to have severe and moderate PTSD.

Table 8. One-way ANOVA test results of PTSD, Empathy and Depression Level according to age level of Syrian children

\begin{tabular}{|c|c|c|c|c|c|c|c|}
\hline Variable & $\begin{array}{c}\text { Age } \\
\text { (Year) }\end{array}$ & $\mathrm{n}$ & $\bar{X}$ & $\mathrm{~S}$ & $\mathrm{~F}$ & $\mathrm{p}$ & $\begin{array}{c}\mathrm{D} \\
\text { (LSD) } \\
\end{array}$ \\
\hline \multirow{4}{*}{ PTSD } & A.8-9 & 91 & 39,20 & 9,08 & \multirow{4}{*}{3,570} & \multirow{4}{*}{$.030 *$} & \multirow{4}{*}{ A-B } \\
\hline & B.10-11 & 120 & 35,74 & 9,52 & & & \\
\hline & C. $12-15$ & 45 & 36,82 & 9,60 & & & \\
\hline & Total & 256 & 37,16 & 9,47 & & & \\
\hline \multirow{4}{*}{ Empathy } & A.8-9 & 91 & 9,64 & 2,04 & \multirow{4}{*}{1,681} & \multirow{4}{*}{.188} & \multirow{4}{*}{ - } \\
\hline & B.10-11 & 120 & 10,14 & 2,09 & & & \\
\hline & C. $12-15$ & 45 & 9,64 & 2,49 & & & \\
\hline & Total & 256 & 9,87 & 2,15 & & & \\
\hline \multirow{4}{*}{ Depression } & A.8-9 & 91 & 31,23 & 5,00 & \multirow{4}{*}{3,879} & \multirow{4}{*}{$.022 *$} & \multirow{4}{*}{$\begin{array}{l}\text { A-B } \\
\text { A-C }\end{array}$} \\
\hline & B.10-11 & 120 & 29,78 & 4,97 & & & \\
\hline & C. $12-15$ & 45 & 28,88 & 5,05 & & & \\
\hline & Total & 256 & 30,14 & 5,05 & & & \\
\hline
\end{tabular}

D: Difference

As a result of the one-way ANOVA analysis applied in Table 8 , there was a statistically significant difference between PTSD and depression level and age level of Syrian children, but no significant difference was found in the level of empathy. According to this finding, the PTSD level $(\bar{X}=9.97)$ of the Syrian children aged 8-9 years was higher than the PTSD level $(\bar{X}=35.74)$ at the age of $10-11$ years $(F$ $=3,570 ; p=0,030<0.05)$. When examined in terms of depression level, depression level $(\overline{\mathrm{X}}=31,23)$ was higher in Syrian children aged $8-9$ years $(28,88)$ than in the case of depression level $(F=3,879 ; p=0,022<0.05)$. It can be said that PTSD and depression level of 8-9 year old children can be affected much more than the others. Similarly, some researchers suggest that young children are generally more likely to show signs of trauma and depression [35].

Table 9. One-way ANOVA test results for PTSD, Empathy and Depression level according to the number of siblings of Syrian children

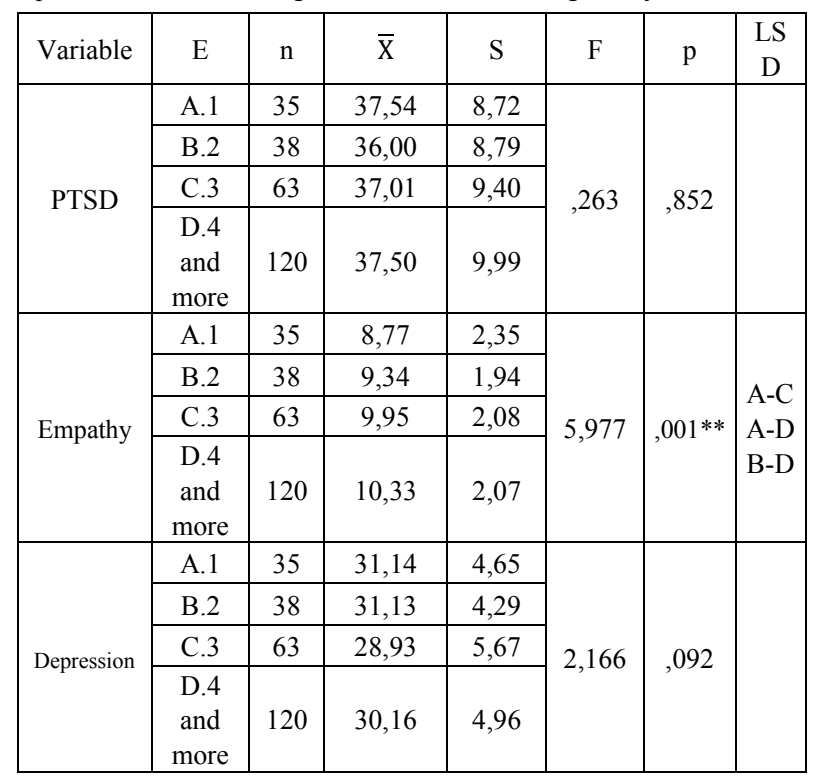

** $\mathrm{p}<.01$ E: Total Number of Brothers and Sisters
The one-way ANOVA analysis applied in Table 9, reveals a statistically significant difference between the empathy level of the Syrian children and the number of siblings. The empathy score of Syrian children who have one sibling $(\bar{X}=8,77)$ was lower than children who have two siblings $(\bar{X}=9,34)$. The empathy score of who have 4 or more siblings $(\overline{\mathrm{X}}=10,33)$ was higher than the children who have 3 or less Siblings. This situation can be interpreted as the level of empathy of Syrian children with fewer siblings is lower than the level of empathy of children with more siblings. This finding shows that if they have more siblings they feel more empathy.

Table 10. One-way ANOVA test results of PTSD, Empathy and Depression level according to Family Average Income Level of Syrian Children

\begin{tabular}{|c|c|c|c|c|c|c|c|}
\hline Variable & $\begin{array}{c}\text { Family Average } \\
\text { Income Level }\end{array}$ & $\mathrm{n}$ & $\bar{X}$ & S & $\mathrm{F}$ & $\mathrm{p}$ & LSD \\
\hline \multirow{4}{*}{ PTSD } & A. $0-600 \mathrm{tl}$ & 61 & 36,37 & 11,42 & \multirow{4}{*}{2,157} & \multirow{4}{*}{, 118} & \\
\hline & B.601-1500tl & 178 & 37,00 & 8,74 & & & \\
\hline & C. $1501-3000 \mathrm{tl}$ & 17 & 41,64 & 8,41 & & & \\
\hline & Total & 256 & 37,16 & 9,47 & & & \\
\hline \multirow{4}{*}{ thy } & A. $0-600$ tl & 61 & 9,95 & 2,18 & \multirow{4}{*}{,329 } & \multirow{4}{*}{, 720} & \\
\hline & B.601-1500tl & 178 & 9,82 & 2,14 & & & \\
\hline & C.1501-3000tl & 17 & 10,23 & 2,27 & & & \\
\hline & Total & 256 & 9,87 & 2,15 & & & \\
\hline \multirow{4}{*}{ Depression } & A. $0-600 \mathrm{tl}$ & 61 & 30,96 & 4,83 & \multirow{4}{*}{3,700} & \multirow{4}{*}{$026 *$} & \multirow{4}{*}{ B-C } \\
\hline & B.601-1500tl & 178 & 29,62 & 4,93 & & & \\
\hline & C.1501-3000tl & 17 & 32,52 & 6,22 & & & \\
\hline & Total & 256 & 30,14 & 5,05 & & & \\
\hline
\end{tabular}

$$
* \mathrm{p}<.05
$$

When the results of the one-way ANOVA analysis applied in Table 10 are examined, although there was no statistically significant difference between the PTSD and empathy level of the Syrian children, there was a significant difference between the family income level and depression level. On the other hand, Jolliffe and Farrington[28] found that empathy was positively associated with the socio-economic situation in his research entitled "Development and Validity of the Basic Empathy Scale". While the average income level of the family was between $0-600 \mathrm{TL}$, the PTSD score $(\overline{\mathrm{X}}=36,37)$ of the Syrian children was lower than the PTSD score $(\overline{\mathrm{X}}=$ 37.00) of the Syrian children having the income level of 601-1500 TL. In terms of depression level, the depression level $(\bar{X}=29,62)$ of Syrian children with income level of 601-1500 TL was found to be lower than the depression level $(\bar{X}=32.52)$ of Syrian children with income level of 1501 and 3000 TL. The finding indicates that the vast majority of Syrian families has a low socioeconomic level. And also, it can be said that that depression level is lower in children whose family income level is lower because they are accustomed living in hard situations and resistant to depression. 


\section{Conclusions}

This research was conducted on 256 Syrian children attending temporary training centers in Altındağ district of Ankara province where migration of Syrian families was intense in 2017-2018 education year. In this study, it was aimed to examine the PTSD, empathy and depression levels in Syrian children who were exposed to traumatic life in terms of some variables. In this study, gender, number of siblings, whether father and siblings are alive, mother's education status, father's education status, average income of the family, father's working status, mother's working status and domestic violence variables were examined in this study.

The literature suggests that there are significant differences in the PTSD indicing according to race, gender and age groups. For example, girls and younger children are more likely to show PTSD statements. Girls show more signs related to emotional processing and emotional reaction to trauma. According to this study, there was no significant relationship between Syrian children and PTSD, Empathy and Depression Scales according to gender factor. The level of trauma of girls was similar to that of boys.

In this study, it was concluded that there was a statistically significant difference between the level of PTSD and depression and the level of age in Syrian children. According to this study, the PTSD level of children aged 8-9 years was higher than the PTSD level at 10-11 years. This indicates that young Syrian children are more affected by the trauma they experience. When analyzed in terms of depression level of Syrian children aged 8-9 was found to be higher than depression level at 12-15 years, similar to PTSD level. This also shows that the younger Syrian children are more affected by the trauma they experienced and their level of depression is higher. According to empathy level, there was no significant difference according to the age level of Syrian children. In this context, it can be said that age is not effective on empathy. Similarly, in a study by Bulut [36], there was no significant difference in terms of gender between girls and boys in the study of PTSD seen in children after the earthquake in terms of age and gender. On the other hand, the trauma level of the younger age group was significantly higher than the middle age group.

In this study, it was found that about half of the Syrian children who participated in the survey had 4 or more brothers or sisters. Although there was a statistically significant difference between the level of empathy of the Syrian children and the number of the siblings, no significant difference was found between the level of depression and PTSD. This indicates that although the number of siblings was not effective on the level of depression and PTSD, but it has an effect on the level of empathy. The study shows that the level of empathy for children with fewer siblings was lower than the level of empathy for children with more siblings.
It is also seen that whether siblings were alive or not was also influential on PTSD and empathy levels. It can be said that the level of empathy for children whose siblings were alive was lower than that for children who were not alive. Sullivan, Saylor and Foster[37] found that psychological problems and traumatic findings persisted after the traumatic event in which a majority of the children were living. The study by Gordon and Wraith[38] also shows that children cannot live without being affected by the traumatic events they experienced, at different levels, without trauma. Because of the fact that children has not yet fully developed, they can be affected more negatively than traumatic events. According to empathy level, the level of empathy of children whose fathers were alive was higher than the children whose fathers were not alive.

In this study, it was found that whether or not children whose fathers were working, has an effect on depression level. According to the trauma level, the level of trauma of children whose fathers were not working was higher than the level of trauma of children whose fathers were not working. Similarly, the level of empathy of children, whose fathers were not working, was higher than the children whose fathers were working. The depression level of the children whose fathers were not working, was higher than the children whose fathers were working. These findings can be explained by the fact that the levels of trauma, empathy and depression of the children whose fathers were not working, were higher than the children whose fathers were working. It can be said that whether or not children whose mothers were working, had an effect on the depression level of children. The level of trauma of children whose mothers were not working, was partially higher than the level of trauma of children whose mothers were working. The empathy level of children whose mothers were working, was higher than the children whose mothers were not working. This finding can be interpreted that the children, whose mothers were working, was a higher level of empathy than the children whose mothers were not working. According to the depression level, the depression level of children whose mothers were not working, were also higher than children whose mothers were working.

According to this study, there was no statistically significant difference between the PTSD and empathy level of the Syrian children according to family income level. A statistically significant difference was found between depression level of Syrian children and family income level. It was found that children with low family income level had lower depression level than children with higher family income level.

In this study, it was found that the presence of violence in the families of children had an effect on trauma and depression levels of children. Trauma levels of children with family violence were higher than trauma levels in children without violence in the family. The empathy levels of children with family violence were also higher 
than the children without violence in the family. Similarly, the depression level of children with family violence was higher than the depression level of children without family violence. These findings can be interpreted as that the levels of PTSD, empathy and depression of children with family violence were higher than children without family violence. One of the factors that make it difficult to determine depression in children is depressive disorders and phobia and adaptation problems in this developmental period [29]. Kisac's[2] study called stress symptoms of the survivors of the recent 2 earthquakes in the Marmara region were compared after 1 year after the earthquake examined people from stress-related symptomatology in Turkey and symptoms with symptoms that earthquake. The questionnaire conducted by the Symptom Check List was conducted by 223 participants in the first administration and 342 participants in the second year and one year later. The survivors of the earthquake were found to have elevated levels in all subscales of the Symptom Checklist, but in the second effect, stress symptoms were reported to be lower in terms of anxiety, phobic anxiety, and psychotic symptoms. In contrast, obsessive-compulsive behaviors were found to have no significant difference in depression, anger, or paranoid thoughts.

The results of this research show that there is a relationship between PTSD, empathy and depression levels of Syrian children and many variables. In the study; that about half of the participants had the number of siblings of 4 or more and that those who were not alive constituted about half of the participants of the siblings, that more than half of the parents' learning levels of the parents were literate or primary school graduates and that the vast majority of the participants had a family average income level of 601-1500 TL empathy and depression. There was no difference between the levels of PTSD, empathy and depression according to gender, whether the mothers were alive or not and whether the fathers were alive or not had no effect on the levels of PTSD, empathy and depression, whether your fathers were alive or not depends on the level of depression, whether the children whose father or mother was working, on depression the effects of domestic violence on the levels of depression and PTSD, the effect of age level on trauma and depression, the effect of family income on depression was found to be influenced by the number of siblings. migrated to a new country due to the war they had experienced, losing their parents, their siblings or their relatives, and not be able to get rid of the traumas they The fact that Syrian children had to leave their countries which increased trauma and depression levels of the children.

According to the findings in this article, the vast majority of Syrian families have a low educational and socioeconomic level. It can be said that, girls were more emotional and cognitive empathy than boys. The war affects especially children. In addition, the war affects boys and girls in the same way. The empathy level of the Syrian children, whose siblings were dead, was higher than the children whose siblings were alive. The reason of this can be they were faced with traumatic events. 25 percent of fathers of Syrian children were not working. The children whose fathers were working may feel more confidence and less depression. The depression level of the children whose mothers were not working was higher than the children whose mothers were working. It can be said that the children whose mothers were working may feel more confidence and less depression. The levels of PTSD, empathy and depression of Syrian children with family violence in the family were higher than the PTSD, empathy and depression levels in Syrian children without family violence. Violence in the family may affect the PTSD and depression level of Syrian children. Younger children can be affected much more than the others. Younger children are generally more likely to show signs of trauma and depression. The level of empathy of Syrian children with fewer siblings is lower than the level of empathy of children with more siblings. According to this finding, the children have more siblings they feel more empathy. The depression level is lower in children whose family income level is lower because they are accustomed living in hard situations and resistant to depression.

The findings obtained in this study are supportive of studies carried out at the national and international level. According to the results of the research, it is suggested that the Syrian children should be given shelter, education and psycho-social support. Psycho-social support for these traumatized children has important tasks for guidance teachers, psychological counselors, psychologists and social workers. Psycho-social support activities should be carried out especially in areas where the Syrians live intensively, in order to ensure the social adaptation of such children.

\section{Acknowledgements}

We are very grateful to guidance teachers, psychological counselors, psychologists, social workers and school directors for taking part in the study and constructive suggestions.

\section{REFERENCES}

[1] N. Saylor After disasters, what about the children? PsycCRITIQUES, 4, 12-18, 1993.

[2] I. Kisac. Stress symptoms of survivors of the Marmara region (Turkey) earthquakes: A follow-up study. International Journal of Stress Management, 13(1), 118., 2006.

[3] R. A. Giaconia, H. Z. Reinherz and A. B. Silverman. Trauma and posttraumatic Stress disorder in a community 
population of older adolescents. Journal of American Academy of Child and Adolescent Psychiatry, 25(3): 384-392, 1995.

[4] American Psychiatric Association Diagnostic and Statistical Manual of Mental Disorders (DSM - III) 3th ed.). Washington, DC., 1980.

[5] G.A. Bonano, S. Galea, A. Bucciarelli, D. Vlahov. Psychological resilience after disaster: New York City in the aftermath of the September 11th terrorist attack. Psychol Sci, vol.17, 181-186, 2006.

[6] WHO. World Health Organization. The ICD-10 Classification of Mental and Behavioural Disorders: Clinical Descriptions and Diagnostic Guidelines, Geneva, 1992.

[7] C. Z. Garrison, M. W. Weinrich, S. B. Hardin, S. Weinrich and L. Wang. Posttraumatic Stress disorder in adolescents after a hurricane. American Journal of Epidemiology, 3, $522-530,1993$

[8] T.M. Keane, L.M. Fisher, K.E. Krinsley, B.L. Niles. Posttraumatic Stress Disorder. In: Hersen, M., Ammerman, R.T. (eds.) Handbook of Prescriptive Treatments for Adults Springer, Boston, MA, 237-260, 1994.

[9] S. Culbertson \&, L. Constant. Education of Syrian Refugee Children, Managing the Crisis in Turkey, Lebanon \& Jordan. Santa Monica, Calif.:RAND Corporation, 2015.

[10] M. N. Emin. Türkiye'deki Suriyeli çocukların eğitimi. Temel eğitim politikaları. SETA Siyaset, Ekonomi ve Toplum Araştırmaları Vakfi: İstanbul. http://file.setav.org/Files/Pdf/20160309195808 turkiyedek i-suriyeli-cocuklarin-egitimipdf, 2016.

[11] Özel Eğitim ve Rehberlik Hizmetleri Genel Müdürlüğü Türkiye'de Geçici Koruma Statüsünde Bulunan Suriyelilere Yönelik Rehberlik Hizmetleri Kılavuzu, 2017.

[12] İ. Coşkun, \& M. N. Emin Türkiye'deki Suriyelilerin Eğitiminde Yol Haritas1: Frrsatlar ve Zorluklar. SETA, 2016.

[13] S. Coffman, Children's reactions to disaster. Journal of Pediatric Nursing, 13,(6) 376-382, 1988.

[14] S. Baron-Cohen, S. Wheelwright. The Empathy Quotient: An Investigation of Adults with Asperger Syndrome or High Functioning Autism and Normal Sex Differences. J Autism Dev Disor, 34: 163-175, 2004.

[15] J. C., Oxley. What is Empathy? The Moral Dimensions of Empathy, 15-32, Palgrave Macmillan, London, 2011.

[16] G. Matthews, M. Zeidner, R. D. Roberts. Emotional intelligence: Science \& myth. London: The MIT Press, 2002.

[17] American Psychiatric Association Diagnostic and Statistical Manual of Mental Disorders (DSM-5), Fifth edition. Washington, DC., 2013.

[18] Ş. Şener. Çocuklarda ve ergenlerde depresyon. Depresyon monografları serisi; 7: 313-326, 1994.

[19] Ş. Büyüköztürk. Faktör analizi: Temel kavramlar ve ölçek geliştirmede kullanımı. Kuram ve Uygulamalarda Eğitim Yönetimi, (32), 470-483, 2002.
[20] C. J. Frederick. Children traumatized by catastrophic situations. In S. Eth, ve R. Pynoss (Ed.), Posttraumatic stress disorder in children. Washington, DC: American Psychiatric Press, 1985.

[21] R.S. Pynoos, C. Frederick, K. Nader and W. Arroyo. Life threat and posttraumatic stress in school-age children. Arc Gen Psychiatry 44:1057-1063, 1987.

[22] G. Erden, E. Z. Kılıç, R. İ. Uslu, ve E. Kerimoğlu. Çocuklar için travma sonrası sress tepki ölçeği: Türkçe geçerlilik, güvenilirlik ön çalışması. Çocuk ve Gençlik Ruh Sağlığı Dergisi, 6 (3), 143-149, 1999.

[23] B.K. Bryant. An Index of Empathy for Children and Adolescents. Child Development Vol. 53, No. 2 Apr., 1982, 413-425, 1982.

[24] A. Mehrabian and N. A. Epstein. Measure of emotional empathy. Journal of personality, 40(4), 525-543, 1972.

[25] A. Yılmaz. Empati Eğitim Programının İlköğretim Öğrencilerinin Empatik Becerilerine Etkisi. Yayımlanmamış Yüksek Lisans Tezi. Ankara: Ankara Üniversitesi Sosyal Bilimler Enstitüsü, 2003.

[26] M. Kovacs. The Emanuel Miller Memorial Lecture Depressive disorders in childhood: an impressionistic landscape). Child Psychology Psychiatry, 1997; 38: 287-298, 1994.

[27] B. Öy. Sene kaybı olan öğrencilerde çocuklar için depresyon ölçeği uygulaması. Türk Psikiyatri Dergisi; 5:139, 142, 1994.

[28] D. Jolliffe, D. P., Farrington. Development and validation of the Basic Empathy Scale. Journal of Adolescence. Volume 29, Issue 4, August 2006, 589-611, 2006.

[29] A. Aysev, B. Ulukol ve Ceyhun, G., Çalışan ve Okuyan Çocukların "Çocuklar için Depresyon Ölçeği" ile Değerlendirilmesi. Ankara Üniversitesi Tıp Fakültesi Mecmuas1 Cilt 53, 27-30., 2000.

[30] A. Cohen, W. Bernet. and J. E. Dunne. Practice parameters for the assessment and treatment of children and adolescents with posttraumatic stress disorder. Journal of American Academy of Child and Adolescent Psychiatry, 37(Suppl 10) 4-25. 1998.

[31] P. Steinglass and E. Gerrity. Natural disaster and post-traumatic stress disorder: Short-term versus long-term recovery in two disaster-affected communities. Journal of Applied Social Psychiatry, 20:1746- 1765, 1990.

[32] S. Alparslan, A. İ. Koçar, S. Şenol ve I. Meral Marmara Depremini Yaşayan Çocuk ve Ergenlerde Ruhsal Bozukluklar ve Kaygı Düzeyleri. Çocuk ve Gençlik Ruh Sağlığı Dergisi, 6(3), 135-142, 1999.

[33] A. Perkonigg, R. Kessler, S. Storz and H. Wittchen Traumatic events and posttraumatic stres isorder in the community: prevalence, risk factors and comorbidity. Acta Psychiatr Scand, 101:46-59, 2000.

[34] E. Okcu. Travmaya maruz kalan çocuklarda tssb gelişimi ve şiddetiyle ilişkili faktörlerin incelenmesi. Yayımlanmamış Yüksek Lisans Tezi. Gaziantep: Hasan Kalyoncu Üniversitesi. Sosyal Bilimler Enstitüsü, 2016.

[35] P. Mitsuko, D. Shannonm, D. Pharm, J.L. Christopher, A.J 
Finch and M.T. Charlotte. Children Exposed to Disaster: I. Epidemiology of Post-Traumatic Symptoms and Symptom Profiles. Journal of the American Academy of Child \& Adolescent Psychiatry. Volume 33, Issue 1, 80-93, 1994.

[36] S. Bulut. Depremden Sonra Çocuklarda Görülen Travma Sonrası Stres Tepkilerinin Yaş ve Cinsiyetler Açısından Karşılaștırılması. Türk Psikolojik Danıșma ve Rehberlik Dergisi, 4 (31), 43-51, 2009.
[37] A. M. Sullivan, F. C. Saylor and K.Y Foster. Posthurricane adjustment of preschoolers and their families. Advance Behavioral Research and Therapy, 13:163-171, 1991.

[38] N. Gordon and R. Wraith. The impact of travma on children and adolescents. (Ed: Pynoos, R. S., Nader, K. ve Black, D.) International handbook of traumatic stress syndromes, 535-657, Beverly; New York, NY, US: Plenum Press, 1993. 